\title{
Role of Locus of Control on Micro Entrepreneurs
}

\section{P. S. Vijay Anand}

\begin{abstract}
This article is focused on the role of locus of control on the micro Entrepreneurs. Micro Entrepreneurs plays a major role in the development of an economy of a county. Every individual has their own beliefs and their level of outcome of their beliefs depends on their own personality. This level of belief was identified and developed by Julian.B.Rotter in 1954. He developed this as a personality study and his study has been applied in various areas in psychology and also in management .Since we know that difference in gender may place a major role in the success of the enterprises. The research is done mainly to understand the level of Locus of control among the Micro Entrepreneurs and also its influence on the difference in gender. The researcher has used the scale introduced by Rotter to evaluate the locus of control amount the micro entrepreneurs. Sample size of $\mathbf{2 0 0}$ is taken in and around kanyakumari District. for statistical analysis. From the analysis it is found that womens are having more External Locus of control than mens who have more Internal Locus of control.
\end{abstract}

Keyword: locus of control, Micro entrepreneurs, Gender Difference

\section{INTRODUCTION}

Rotter believes that internal and external Locus of control are the two extreme ends and the person with internal LOC feels that outcomes of the result is based only on his own efforts and there is no luck or fate influence on it. And person with External LOC feels that outcomes of the result is based only on fate and luck and they have no control over the outcomes and they also find reason for their failures.

People with internal LOC also feels more anxiety and nervous and mostly fall under physiological problems if they can't find success through their effort in other case people with external LOC are easy going and work relaxed without much mental tension.

Rotter used 23-item questionnaire to measure the locus of control , points are given based on the questionnaire and the scores are calculated it.

Micro Enterprises are the base for the growth of GDP in a country, hence small scale enterprises are booming very fast in all over the country. Micro enterprise also provide lot of job opportunity and also gave space from more new entrepreneurs and reduce the unemployment problem of the country.

A Micro Enterprise is a small business that employs a small number of employees. A microenterprise will generally operate with less than 10 people and is started with a small amount of Investment.

Revised Manuscript Received on December 12, 2019.

* Correspondence Author

P.S.Vijay Anand*, Assistant Professor, Department of Management Studies, Narayanaguru College of Engineering, Kanyakumari District.

(c) The Authors. Published by Blue Eyes Intelligence Engineering and Sciences Publication (BEIESP). This is an open access article under the CC BY-NC-ND license (http://creativecommons.org/licenses/by-nc-nd/4.0/)
Most microenterprises concentrate in providing goods or services for their local areas. Now a days we can see a huge growth of small entrepreneurs emerging in all the fields and their success is depends on their self efficiency and their motivational level.

Most of the entrepreneurs are find difficult to run their enterprises due to heavy competition and also their business are now a days heavily affected by online business sectors Recent years we can see more women entrepreneurs are emerging in all the fields equal to men. They also have more self efficacy to face the environment and also to effectively run the enterprises. This study aims to identify the influence level of locus of control on Micro Entrepreneurs as most believe that success of the entrepreneurs depend on the influence of self-efficacy of the individuals.

\section{OBJECTIVE OF THE STUDY}

The main aim of the research is to find out the level of Locus of Control in Micro Entrepreneurs.

\section{HYPOTHESIS}

Keeping the objectives in mind the Hypothesis is framed, $\mathrm{HO}=$ There is no significant difference between locus of control among women and men Micro Entrepreneurs $\mathrm{H} 1$ = There is significant difference between locus of control among women and men Micro entrepreneurs

\section{REVIEW OF LITERATURE}

Gender difference in locus of control has been found in adults in the year (2005) by Schultz and Schultz in the U.S. But the authors has quoted that there may be some category of questions may influence the gender based bias.

Another study done by Takaki year (2006) among hospital patients says that females have high Internal Locus of control than male related to compliant in health.

Another study done in the year 2018 says that young girls have more External Locus of control than young boys.

Brockhaus and others found out that entrepreneurs with Internal Locus of control have great chance of success in the business than the people with External Locus of control. Hence Internal Locus of control acts as success for entrepreneurial success

In research on self efficacy also proves that person with Internal Locus of control have more self efficacy than person with External Locus of control.

In 1989 Smith has found that locus of control has only little influence on measuring the self-efficacy, he explains that training may create changes in the person behavior.
Published By:

\& Sciences Publication

(C) Copyright: All rights reserved. and $\mathrm{Hum}_{\mathrm{m}}$
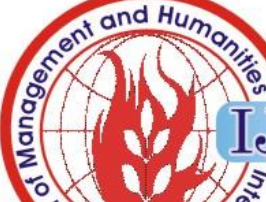

Q IJMH 


\section{Role of Locus of Control on Micro Entrepreneurs}

In the literature study it is clearly found out that locus of control is influenced with the behavior of the people who have taken entrepreneur as a career. As most of the authors has concentrated on the macro level entrepreneurs and since no much reviews were done in the micro level this study

will be a good input in the area of study. This study may helps to know about that level of locus of control and their risk bearing capability and self efficiency.

\section{METHODOLOGY}

The sample size contains 200 participants both men and women between the age group of 18 to 50 years were taken eventually. 100 men and 100 women entrepreneurs were selected for the study. They all been running a micro enterprises in kanyakumari district for at least 10 years. Random sampling technique was used for sample selection. Data were collected from participants from their own enterprises. comparative group research study was designed. A less number of participants were in current research because most of the entrepreneurs were having language barriers to fill the questionnaire and also not willing to participate in for the study.

Research Design: The study was based on research design comparative group method. Locus of Control was scale is used in both genders among the Micro Entrepreneurs

\section{Research tool:}

Rotter's (1996) 29 item Locus of Control scale questionnaire developed by Rotter (1966) is used to measure the locus of control among micro Entrepreneurs.

\section{Methods :}

To measure the intensity of locus of control in Micro Entrepreneurs, 29 item scale created by Rotter (1966) was used .For the reason of collection of data , data was collected from different Micro Entrepreneurs . Sample contains 200 entrepreneurs , 100 male, and 100 female between the ages of 18 to 50 years . Then the data were collected from all the entrepreneurs ,Participants were informed about the objectives of the study and also genuine response were asked to submit during the data collection period.

After the development of data compilation the researcher interpret the data for further process. In this research t-test was used for the statistical analysis of the data .

\section{ANALYSIS \& FINDINGS}

This study is to find out the locus of control in Micro Entrepreneurs. This study also tries to give out whether LOC has significant difference with the gender and also data from 200 Micro Entrepreneurs were collected from different parts of kanyakumari District. To measure the level of influences Rotter(1966) questionnaires were used and t test is used to find out the difference on locus of control among men and women entrepreneurs. Hypotheses were framed to compare between both independent variables.

Table $6.1 \mathrm{t}$ - test

\begin{tabular}{|c|c|c|c|c|c|c|c|}
\hline Variable & Gender & $\boldsymbol{N}$ & $\boldsymbol{M}$ & $\boldsymbol{S D}$ & $\boldsymbol{d} \boldsymbol{f}$ & $\boldsymbol{t}$ & $\boldsymbol{P}$ \\
\hline \multirow{2}{*}{ LOC } & Female & 100 & 9.46 & 2.29 & \multirow{3}{*}{198} & \multirow{3}{*}{5.77} & \multirow{2}{*}{.000} \\
\cline { 2 - 8 } & Male & 100 & 11.33 & 2.29 & & & \\
\hline
\end{tabular}

The above table shows that there is a significant difference between men and women entrepreneurs on LOC $\mathrm{p}<* 0.05$ level. The hypothesis also tested by comparing the data by independent sample t test. From this test it is found that men entrepreneurs have more Internal Locus of control then women entrepreneurs .

\section{CONCLUSION}

Role of locus of control on Micro Entrepreneurs shows that the self efficacy of the entrepreneurs are mostly depends on the level of locus of control and also there is high gender based difference is found among the entrepreneurs. Women are having more External Locus of control where as men have more Internal Locus of control. This study also shows that men can take more risk and also hard work for making the enterprise more successful.

\section{REFERENCES}

1. Wadsworth:from http://en.wikipedia.org/wiki/Locus_of_control.

2. Dharmaratne KLBG (2012). Impact of individual factors on the business performance of women entrepreneurs(1):139-165

\section{AUTHORS PROFILE}

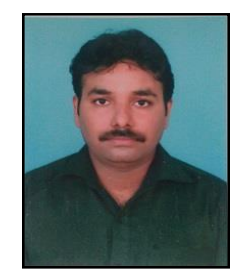

P.S.Vijay Anand M.Sc (Engg),. M.B.A. (Ph.D) Assistant Professor Department of Management Studies, Narayanaguru College of Engineering, Kanyakumari District. He has around 9 years of Industrial Experience in the field of IT and 5 years of Teaching Experience in the field of Management , He has attended many National and International conference and presented papers. Currently doing research in the Area of HR in Bharathiar University Coimbatore. 